\title{
The Influence of Job Resources Toward Employee Engagement and Its Impact On Turnover Intention of the Employees of PT Bank DKI
}

\author{
Tinjung Desy Nursanti \\ Bina Nusantara University \\ tinjungdesy@yahoo.com
}

\author{
Theresha Then \\ Bina Nusantara University \\ itheresha@yahoo.com
}

\begin{abstract}
The purpose of this study was to determine the influence of job resources toward employee engagement and its impact on turnover intention either partially or simultaneously as well as providing advice to the management of PT Bank DKI to its employees. The method used is the associative method where data are primarily collected through interview, and distributing questionnaires to 100 employees as respondents, as well as obtaining secondary data through the study of literature. The data is processed through path analysis method. From the data analysis, it is found that job resources have a positive and significant effect on employee engagement, but, job resources have negative and not significant on turnover intention. Another result obtained is that employee engagement has a negative and significant effect on turnover intention. While simultaneously, job resources and employee engagement have a negative and significant impact on turnover intention
\end{abstract}

Keywords: Job Resources, Employee Engagement, Turnover Intention

\begin{abstract}
Abstrak
Tujuan penelitian ini adalah untuk mengetahui bagaimana pengaruh job resources terhadap employee engagement dan dampaknya pada turnover intention baik secara parsial maupun simultan serta memberikan saran kepada pihak manajemen PT Bank DKI terhadap karyawannya. Metode penelitian yang digunakan adalah metode asosiatif dimana data yang digunakan adalah data primer yang diperoleh melalui wawancara, dan menyebarkan kuisioner kepada 100 orang karyawan sebagai responden dengan menggunakan cara Cross Sectional. Seperti hal nya data sekunder yang diperoleh melalui studi literatur. Data tersebut diolah melalui analisis jalur (path analysis). Dari hasil analisis data, diperoleh bahwa job resources berpengaruh positif dan signifikan terhadap employee engagement tetapi job resources berpengaruh negatif dan tidak signifikan terhadap turnover intention. Hasil lain didapat adalah employee engagement berpengaruh negatif dan signifikan terhadap turnover intention. Secara simultan, job resources dan employee engagement berpengaruh negatif dan signifikan terhadap turnover intention
\end{abstract}

\section{Kata Kunci: Job Resources, Employee Engagement, Turnover Intention}

\section{Introduction}

Human resources as capital are important assets and needed to be managed professionally because every organization expects competent, loyal, and human resources that are closely related to the company, even greater than just loyal (engaged) people. The relationship between employees and organizations despite reflecting on having a formal legal document that ties in the form of written agreements tends to break up due to various factors (Adryanto, 2014: 10). Since the era of the industrial revolution began, the phenomenon of the discharging employees has become commonplace. There is no bond that can ensure employee employment can last until official employees retire (Adryanto,
2014:17). This is proven by the 2012 Global Workforce Study, which included 29 countries, including Indonesia, with a total of 32,000 employees. Twothirds of employees in Indonesia do not have high engagement with their organizations. In fact, the survey also mentions that around $27 \%$ of employees currently plan to move in the next two years. The same is found through the survey of Price Waterhouse Coopers (2014) of the banking industry in Indonesia, which is showing that turnover in this sector reaches $15 \%$. The two survey results above show that the turnover rate in the banking sector is quite high. According to Adryanto (2004:18), if the turnover rate is more than $10 \%$, it is considered nerve-racking, and the organization needs to take 
Table 1. pre-test about engagement and turnover intention

\begin{tabular}{ccc}
\hline & Unlike the current job & Stay in the organization \\
\hline Yes & $60 \%$ & $70 \%$ \\
No & $40 \%$ & $30 \%$ \\
\hline
\end{tabular}

Source: research results, 2015

corrective steps.

If an employee decides to leave the organization, this means that the employee has a desire to leave the organization first. This desire should be avoided by the organization through steps that can retain employees.

Nowadays, employee engagement is the basis of the entire organization as one of the strategies or steps to maintain and manage human resources. According to Adryanto (2014: 158), employee engagement is the level of employee commitment or someone to the organization that shows the extent to which they want to work hard and how long they want to continue to join the organization as a consequence of the commitments made. Employee engagement will produce three elements (3S), namely, Say (talking positively about the organization), Stay (staying in the organization), and Strive (motivated to work more seriously). Sridevi (2010: 94) also explained that employee engagement is closely related to employee retention, which means that good employee engagement can reduce turnover intention and directly reduce turnover rates.

Meanwhile, Das and Mishra (2014: 227) through literature analysis explain that job resources which include role clarity, supervisory support, peer support, and organization support are the key drivers that influence employee engagement. According to Ryan et al. (1985 in Bakker and Demerouti 2008: 221), job resources are assumed to be the role of intrinsic motivation because it helps the development and learning of employees, and has the role of extrinsic motivation because it plays an important role in achieving work goals. Through the above research and analysis, it can be developed that job resources affect employee engagement, as where the level of engagement also affects the level of turnover intention.

The object of this research is a regional-owned commercial bank, namely the Jakarta Capital Region Development Bank, which is a bank in Indonesia. This bank was established on April 30, 1961, and headquartered in Central Jakarta with the intent and purpose of helping and encouraging economic growth and regional development in all fields as well as one source of regional income in order to improve the living standards of the people. In 1999,
Bank DKI changed the form of a legal entity from a regional company to a limited liability company.

Based on the Price Waterhouse Coopers survey (2014) which states the high level of employee turnover in the banking sector due to the lack of human resources availability is inversely proportional to turnover in PT Bank DKI, based on the results of interviews with human resource groups, it is known that employee turnover at PT Bank DKI was not high in terms of under $10 \%$. Therefore, to ensure whether the phenomenon really happens, a preliminary test was conducted. The pre-test about engagement and turnover intention was distributed to 30 (thirty) employees of PT Bank DKI, whose results are summarized in Table 1.

Based on the results of the pre-test conducted, it is known that $70 \%$ out of the 30 (thirty) employees decided to remain in the organization or did not wish to find another job, while the remaining 30\% decided to look for another job. Whereas related to the issue of engagement on their work it was found that $60 \%$ of the employees of the 30 (thirty) studied stated that they did not love their jobs, this meant that there was no emotional bond to their work.

The pre-test results above show that most employees do not have a high turnover intention, but it can also be seen that most employees do not have an attachment to their work. This is certainly an interesting subject because based on research developed by Schaufeli et al. (2004 in Takawira 2014: 4) that turnover intention is high due to the absence of work involvement. Halbesleben (2010 in Takawira 2014: 4) also states that there is a significant relationship between work engagement and turnover intention. For now, it is true that PT Bank DKI's turnover intention is not worrying, but for the next few years, no one will ever know how employees decide when they have no attachment at work. This is a matter that must be corrected by examining the causes of employee attachments and examining what makes employees survive so that they can continue to be improved which is useful to prevent high levels of employee turnover. Therefore, a study was conducted entitled the effect of job resources on employee engagement and its impact on the turnover intention of PT Bank DKI Jakarta employees. 


\section{Theoretical Review}

Based on a convention of resource theory according to Hobfoll (2002 in Suan and Nasurdin 2013: 319) resources are objects, personal characteristics, conditions, or energy that are valued by individuals or that function as a means of achieving other sources of information. When individuals have job resources at a high level, they tend to be more energetic, dedicated, and passionate about their work, all of which are characterized by high employee engagement.

According to Schaufeli et al. (2007 in Suan and Nasurdin 2013: 320) Job resources are defined as physical, social, psychological, or organizational aspects of work that are important in achieving work goals, able to reduce job demands, and be able to encourage personal growth, learning, and development. Schaufeli and Arnold (2004 in Frans 2013: 368) also explained that job resources are the role of intrinsic motivation through employee growth, learning and development. Whereas as a role, extrinsic motivation plays an important role in achieving work goals. So it can be concluded that job resources are sources that are able to motivate employees to achieve work goals, encourage growth and development, and as a source to reduce the demands of work

Schaufeli et al. (2004 in Suan and Nasurdin 2013: 321) explain that job resources are divided into 4 (four) levels, which are used as job resources dimensions, as follows:

Organization level, namely organization support consisting of training, technology, and supervision.

Interpersonal levels, namely social support from superiors (supervisory support) and colleagues (peer support).

Work level, namely the role of clarity or role clarity.

Task levels, namely performance feedback (feedback), job control (job control), and autonomy (autonomy)

Lately, employee engagement has become a topic that is often discussed because many studies show that engaged employees are valuable human capital. Saks (2006 in Schaufeli 2013: 7) defines employee engagement as construction that consists of cognitive, emotional, and behaviours related to the role of the individual in work. Khan (1990 in Albrecht 2010: 35) defines employee engagement as someone's involvement, satisfaction, and enthusiasm to work where individuals play a role in their work, are bound, and express themselves physical- ly, cognitively, and emotionally in carrying out their roles.

The same thing is explained by Gallup (in Sridevi 2010: 90) that employee engagement is involved with and enthusiasm for work. Gallup also likens employee engagements as emotional ties and commitment. Employee engagement is also interpreted as a person's positive attitude as defined by Robinson et al. (2004 in Sridevi 2010: 90) that employee engagement is a positive attitude towards the organization and its value. According to Robbins and Judge (2013: 77) employee engagement is defined as a condition where employees have a passion for their work and feel a deep relationship for their organization, while employees who do not have attachment or engagement basically put the time to work but do not have energy or attention to their work. Therefore, it can be concluded that employee engagement is a positive attitude in the form of involvement, enthusiasm, and emotional ties that are related to the role of individuals in work and relationships with their organizations.

According to Baumruk and Gorman (2006 in Sridevi 2010: 92), engaged employees directly display 3 (three) general behaviours that are able to improve the organization, namely:

Say - employees will talk positively about the organization and support the organization

Stay - employees have a deep desire to become members of the organization and ignore opportunities in other organizations.

Strive - employees provide maximum effort and initiative to contribute to the organization.

Whereas in the Perrin report (2003 in Sridevi2010: 92), employees who are not bound or have low engagement tend to behave as follows:

Spinning - throwing effort and expertise on a task or problem that is not important

Settling - does not indicate a commitment to the organization

Splitting - does not attempt to participate or take the initiative in the organization.

The employee engagement model was developed by Saks (2006 in Das and Mishra 2014: 224) that employee engagement consists of 2 (two) dimensions, namely job or work engagement and organization engagement.

\section{Job or Work Engagement}

Refers to the extent to which an individual is interested in his work and performance, and the degree to which an individual has a role in a job, which measures 3 (three) dimensions namely Vigor, Dedication, and Absorption.

Vigor as one of the three main components that 
refers to high energy levels, lack of fatigue, mental endurance during work and willingness and optimism even in the face of difficulties and challenges

Dedication is an important feeling, inspiration, pride, challenge and enthusiasm at work. This happens when a certain employee is really happy in his job.

Absorption Referring to workers who are concentrated and happy in doing work, time passes quickly and is difficult for employees to release themselves from work. In working, employees tend to forget about things around them.

\section{Organization of Engagement}

Refers to the extent to which an individual psychologically feels like a member of an organization, that is having a sense of belonging and as a member of an organization. According to Albrecht (2010: 38), organization engagement is divided into 2 (two) aspects, namely identification and alignment.

Identification refers to the emotional bond experienced by employees and organizations and is also called affective commitment. Employees with a high level of affective commitment will have a strong sense of belonging to the organization.

There is harmony in the suitability of the employee's confidence level with the direction of the organization, goals and values of the organization

Robbins and Coulter (2007: 389) define turnover as "the voluntary and involuntary permanent withdrawal from an organization" if translated is a permanent and voluntary withdrawal from the organization. Mathis and Jackson (2011: 159) suggest turnover as a process where employees leave the organization, and the position of the job must be replaced by someone else. Moreover, turnovers can be classified into various types, as follows:

1. Involuntary and Voluntary Turnover

Voluntary turnover is the discharge of employees from the organization at the request of the employee, usually in the form of early retirement and resignation. The phenomenon of voluntary turnover occurs because employee disaffection stemming from the employee's interpersonal and Involuntary turnover is the discharge of employees from the organization because of being dismissed from their work by the organization concerned, and this can be in the form of Termination of Employment or Layoffs.

\section{Functional and Dysfunctional Turnover}

Functional turnover occurs that employees who have low performance, this is good even though organizational turnover will be high, but the benefits are only those who are competent will stay.
Meanwhile, functional turnover is the departure of good or competent employees from the organization, usually due to the lack of potential development they expect.

\section{Uncontrollable and Controllable Turnover}

Uncontrollable turnover is a turnover that occurs due to factors outside the organization, such as geographical location. Meanwhile, Controllable turnover is a turnover that occurs due to work environment factors, such as compensation.

Based on the Mobley et al. model (1978 in Martin 2011: 7) turnover intention is preceded by a process where a decision is considered before leaving the organization, as follows:

Intention to quit, which reflects the individual intending to leave is seen from the behaviour of a person during work, usually starting with high absenteeism and absenteeism before someone determines the attitude to leave the organization.

Job search, which reflects individuals who wish to find another job.

Thinking of quit (reflecting out) which reflects the individual to think before taking a stand out, he will think in the framework of his decision, quit his job or remain in his work environment. This is because considering having a risk of loss or profit as a result

According to Harnoto (2002: 2), the turnover intention is characterized by various things concerning employee behaviour, namely:

1. Increased attendance

Employees who wish to change jobs are usually marked with increased absenteeism. The level of employee responsibility in this phase is very less compared to before.

2. Getting lazy to work

Employees who wish to change their job will be lazier to work because the orientation of this employee is to work in other places which are considered more capable of fulfilling all the desires of the employee concerned.

3. An increase in violations of work rules Various responsibilities regarding the work environment are often carried out by employees who will do turnover. Employees often leave the workplace when the work takes place, as well as various other forms of violations.

4. Increased protest against superiors.

Employees who wish to change jobs more often protest against company policies to superiors. The protest material that is emphasized is usually related to reciprocal services or other rules that do not agree with the wishes of employees. 5. Positive behaviour is very different from the 


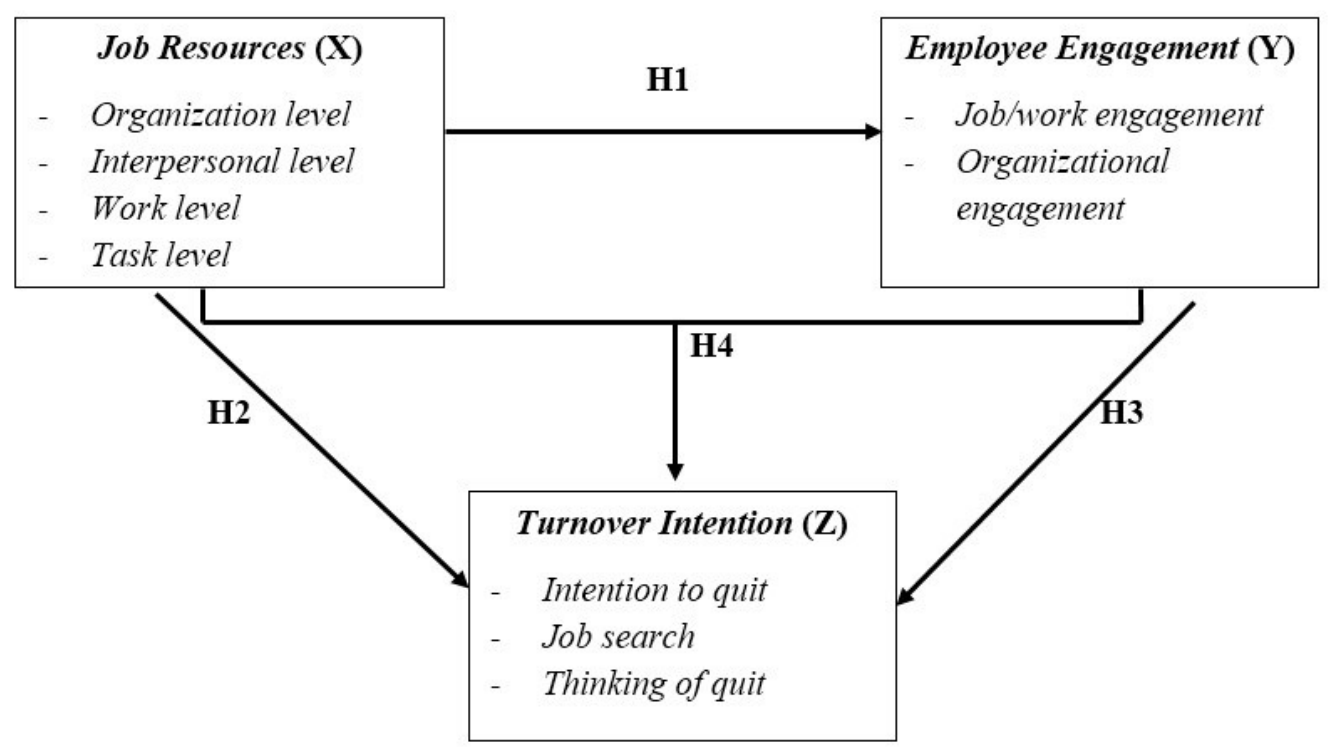

Figure 1. The Research Framework

usual.

This employee has a high responsibility for the assignment that is charged, and if the positive behaviour of these employees increases far and differently than usual, it shows this employee will do turnover.

Based on the theoretical foundation, the research framework is needed as a flow of thought as well as a basis for compiling research hypotheses. The preparation of the framework also makes it easier for the reader to understand the main problems examined in this study. The complete framework of thinking can be seen in Figure 1.

\section{Research Methods}

This research is quantitative research where, according to Sugiyono (2013: 23) is interpreted as a method based on positivism philosophy to examine certain populations or samples and test the hypotheses that have been set. The quantitative method consists of 2 (two) methods, namely, survey and experiment, wherein this study uses a type of quantitative survey, namely quantitative research from interviews or questionnaires. The time range used is one-shot (cross-section) were data taken in the same period from several similar sources. Whereas, the nature of the research is associative causal, namely research that has the nature of asking for a causal relationship between two or more variables (Sugiyono 2013: 37).

The pre-test results above show that most employees do not have a high turnover intention, but it can also be seen that most employees do not have an attachment to their work. This is certainly an interesting subject because based on research developed by Schaufeli et al. (2004 in Takawira 2014: 4) that turnover intention is high due to the absence of work involvement. Halbesleben (2010 in Takawira 2014: 4) also states that there is a significant relationship between work engagement and turnover intention. For now, it is true that there is nothing to worry about the employees' turnover intention at PT Bank DKI Jakarta, however, for the next few years, no one will ever know how employees decide when they have no attachment at work.

This is a matter that must be corrected by examining the causes of employee attachments and examining what makes employees survive so that they can continue to be improved which is useful to prevent high levels of employee turnover. Therefore, a study was conducted entitled the effect of job resources on employee engagement and its impact on the turnover of the intention of PT Bank DKI Jakarta employees."

Before analyzing with path analysis, first to take steps to fulfil the path analysis assumption, as follows:

1. Transformation of ordinal data into intervals with the MSI method.

2. Analysis of validity, to find out which questionnaire items are valid and can be used.

3. Reliability analysis, to determine the reliability and consistency of respondents' answers.

4. Analysis of normality, to find out the distribution of data with normal distribution or not

5. Heterocatalytic analysis, to determine the variance of the same variable or not.

6. Multicorrelation analysis, to find out the relationship between independent variables.

7. Linearity analysis, to find out data on linear lines or not . 
Table 2. Descriptive Statistics

\begin{tabular}{lll}
\hline Variable & Mean Value & Interpretation \\
\hline Job Resources $(X)$ & 4,10 & Good \\
Employee engagement $(\mathrm{Y})$ & 4,10 & Good \\
Turnover Intention $(\mathrm{Z})$ & 3,26 & Enough \\
\hline
\end{tabular}

8. Correlation analysis, to find out the relationship between variables.

The above method is used to answer hypothesis questions as follows:

H1: How does the influence of job resources (X) affect employee engagement (Y) partially or simultaneously on PT Bank DKI?

$\mathrm{H} 2$ : What is the effect of job resources $(\mathrm{X})$ on turnover intention $(\mathrm{Z})$ partially on PT Bank DKI?

H3: What is the effect of employee engagement (Y) on turnover intention $(Z)$ partially on PT Bank DKI?

H4: What is the effect of job resources (X) on employee engagement $(\mathrm{Y})$ and the impact on turnover intention $(\mathrm{Z})$ simultaneously on PT Bank DKI?

\section{Result and Discussion}

After testing the validity, reliability, normality, heteroscedasticity, multicorrelation, linearity and correlation, before analyzing the path, the results of the descriptive statistical test will be interpreted in terms of job resources (X), employee engagement $(\mathrm{Y})$, and turnover intention $(\mathrm{Z})$ variables. Descriptive statistical interpretations will begin with making criteria regarding the meaning of the value of each variable. To make the criteria, the number of classes is first determined by five classes, consisting of the first class "strongly disagree", the second class "disagree", the third class "disagree", the fourth class "agree", the fifth class "strongly agree". Next, use the Sturges formula for the class width, that is (Xmax - Xmin) / Class Number.
Based on the criteria made, an assessment of the mean of each variable can be carried out as follows table 2.

Results of sub-structure analysis 1 (Job Resources and Employee Engagement)

1. Employee Engagement (Y) is influenced by Job Resources (X) simultaneously at $10.4 \%$, and the remaining $89.6 \%$ is influenced by other variables outside of this study.

2. Job Resources $(X)$ has a significant influence on Employee Engagement (Y), the influence is 0.322 or $10.3 \%$. Where if job resources increase, employee engagement will also increase.

Results of analysis of sub-structure 2 (Job Resources, Employee Engagement, and Turnover Intention)

1. Turnover Intention $(Z)$ is influenced by Job Resources (X) and Employee Engagement (Y) simultaneously at $12.9 \%$, and the remaining $87.1 \%$ is influenced by other variables outside of this study.

2. Job Resources (X) has a non-significant effect on Turnover Intention $(Z)$. the direct effect is -0.073 or $0.5 \%$, the indirect effect is -0.121 or $1.46 \%$. While the effect of job resources (X) on turnover intention (Z) through employee engagement $(\mathrm{Y})$ is -0.194 or $3.7 \%$.

3. Employee Engagement (Y) has a significant influence on Turnover Intention (Z). The influence is -0.376 or $14.1 \%$. Where if

Table 3. Summary of the Influence Results based on Path Coefficient

\begin{tabular}{lllll}
\hline $\begin{array}{l}\text { Variable } \\
\text { Influence }\end{array}$ & $\begin{array}{l}\text { Path Coef- } \\
\text { ficient }\end{array}$ & \multicolumn{4}{l}{ Effect result } \\
\cline { 3 - 5 } & & Direct & Indirect & Total \\
\hline X to Y & 0,322 & 0,322 & - & 0,322 \\
X to Z & $-0,073$ & $-0,073$ & $0,32 *_{-}$ & $-0,194$ \\
& & & $0,376=-$ & \\
& & & 0,121 & \\
Y to Z & $-0,376$ & $-0,376$ & - & $-0,376$ \\
$\varepsilon_{1}$ & 0,94 & 0,94 & - & 0,94 \\
$\varepsilon_{2}$ & 0,93 & 0,93 & - & 0,93 \\
\hline
\end{tabular}




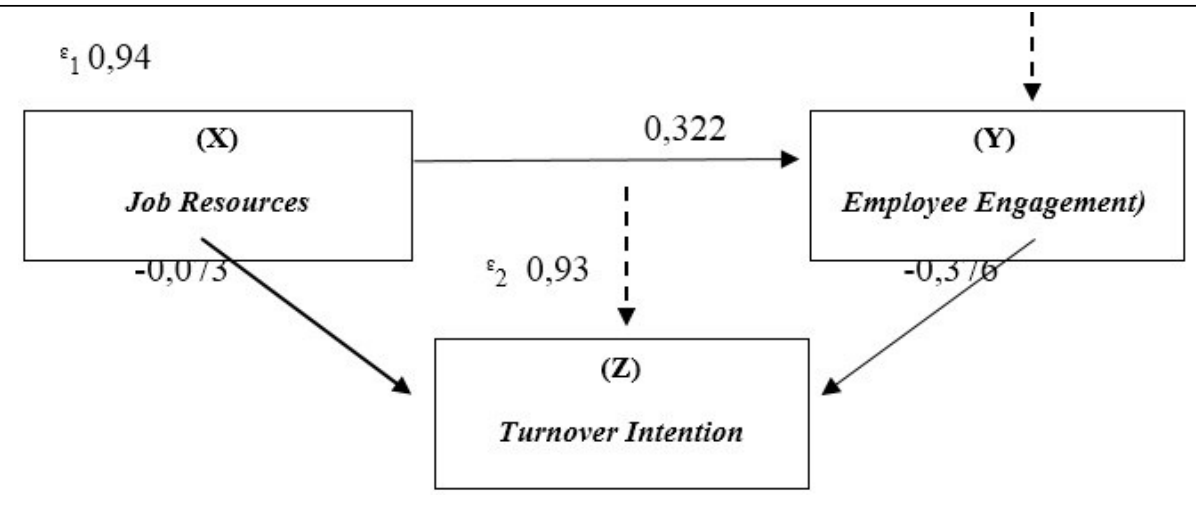

Figure 2. Total Path Diagram of Research Structure

employee engagement rises, there will be a decrease in turnover intention.

Table 3 is a summary of the results of influence based on the path coefficients obtained.

The description of the overall path coefficient results obtained based on path analysis are as follows in figure 2.

\section{Discussion}

Job resources variable (X) in PT Bank DKI has a mean value of 4.10 This indicates that job resources on employees are running well. From the results of the questionnaire, for 12 (twelve) questions with 4 (four) dimensions, the highest dimension on job resources is work level, where most employees state that they clearly understand the duties and responsibilities and understand how to complete their work. This indicates that the organization has provided a description of the task and the right direction in completing the task so that they obtain clarity of purpose of their duties in the organization and the course of organizational activities will not be hampered.

In addition, in job resources variable (X) there are also things that must be corrected by the organization that can be seen in the average value that shows lower than the other average, namely interpersonal levels that employees feel they do not always get support from superiors in the form of assistance when finishing a difficult job. To overcome the problem of the job resources variable perceived by employees on the interpersonal level dimension, the things that can be done by PT Bank DKI with improvements in leadership, for example by directing all bosses on how to direct, motivate, and help subordinates. Another thing that can be done is through supervisor support in providing assistance in work.

The variable employee engagement $(\mathrm{Y})$ in $\mathrm{PT}$ Bank DKI is considered good with a mean value of 4.10. From the results of the employee engagement questionnaire through 8 (eight) questions with 2 (two) dimensions, the dimension that gets the highest average is organization engagement, where most employees state that they are proud to be part of the organization and proud to tell others where they work. While at the lowest average on work engagement that most employees feel that they are not enthusiastic at work, this feeling arises if an employee does not enjoy or love his job. Things that might influence because there are no good job resources because employees feel they don't always get support from their superiors in the form of assistance when completing difficult work. Another thing that can cause employees to feel unenthusiastic because of the work factor itself, where if the job is monotonous, it tends to cause boredom and make employees not enthusiastic in working.

It is possible to improve work engagement through support from superiors on how to complete work and through the provision of training and development programs for each employee, where employees can improve their capabilities in different fields of work or positions so that there is a clear career growth that makes employees feel work different from before. In addition, there are several steps that can increase employee enthusiasm for work, namely:

- Job rotation, namely the movement of workers from one job to another in a work unit

- job enlargement, means that an employee is given a task that is still at one level with the main work.

- Job enrichment means that an employee is given a task whose level is above the main work at this time. This will increase employee responsibility.

The variable turnover intention at PT Bank DKI is considered sufficient with a mean value of 3.26. It is known that the turnover intention $(Z)$ variable will decrease if the variables $\mathrm{X}$ and $\mathrm{Y}$ increase. From the results of the questionnaire research through 5 (five) questions with 3 (three) dimensions. So on turnover intention, the highest average 
in that most employees of PT Bank DKI find it easy to get a job elsewhere, while the lowest average is that employees want to remain in the organization and not think of quitting the organization. This is due to a strong organization engagement where employees feel proud to work at PT Bank DKI, but employees find it easy to get another job because there are many jobs, especially in the same field.

To maintain a low turnover intention level can be through an increase in employee job resources and employee engagement to reduce the level of desire of employees to move.

\section{Conclusion and Suggestion}

As the purpose of this study is to find out how the influence of Job resources on employee engagement and its impact on turnover intention, then after testing with path analysis, it can be concluded that:

1. Job resources variables have a significant effect on employee engagement partially.

2. Variable Job resources do not have a significant effect on partial turnover intention.

3. Employee engagement variables have a significant influence on partial turnover intention.

4. Variable Job resources and employee engagement have a significant influence on turnover intention simultaneously.

The suggestions that can be given based on this research to the company are:

To overcome the problem of job resources variables perceived by employees on the dimensions of interpersonal level, the things that can be done by PT Bank DKI with improvements in terms of leadership, for example by directing all bosses on how to direct, motivate, and help subordinates. Another thing that can be done is through supervisor support in providing assistance in work.

Things that might improve work engagement through support from superiors on how to complete work and through the provision of training and development programs for each employee, where employees can improve their capabilities in different fields of work or positions so that there is a clear career growth that makes employees feel a different job than before. In addition, there are several steps that can increase employee enthusiasm for work, namely:

- Job rotation is the movement of workers from one job to another in a work unit

- Job enlargement means that an employee is given a task that is still at one level with the main work.

- Job enrichment means that an employee is given a task whose level is above the main work at this time. This will increase employee responsibility.

To be able to maintain a low level of turnover intention, PT Bank DKI can increase job resources and employee engagement to reduce turnover intention.

\section{Limitations}

It can be seen in this study that the level of turnover intention at PT Bank DKI is low, which means that the assumption that the high turnover rate of intention in the banking industry is not entirely true. Then future research can examine what variables can affect low turnover intention other than employee engagement. In addition, further research can also examine the influence of generations on employee engagement and turnover intention. There is also better if the next study separates the two dimensions of employee engagement, namely, work engagement and organizational engagement. This is so that the next research is clearer, which dimensions actually affect the low turnover intention level. In addition, another variable that can be included is leadership to determine whether leadership influences one's work engagement and organizational engagement.

For the influence of job resources on employee engagement, it is better if the dimensions of the job resources, namely organization level, work level, task level, and interpersonal level are analyzed one by one on employee engagement, the goal is to know which dimensions influence the strong or not engagement.

\section{References}

Adryanto, M. (2014). Engaging Talents. Jakarta: Prasetiya Mulya Publishing.

Ajzen, I. (2005). Attitude, Personality, \& Behavior. Second Edition. USA: McGraw-Hill, Inc.

Albrecht, S. (2010). Handbook of employee engagement. UK: Edward Elgar Publishing Limite.

Barres, A. 5 Februari (2014). 2013 Turnover Rates by Industry, accessed 5 January 2015 from http://www.compensationforce.com

Biswas, S., Bhatnagar, J. (2013). Mediator Analysis of Employee Engagement: Role of Perceived Organization Support, P-O Fit, Organizational Commitment and Job Satisfaction. Research. 38 (1):27-40.

Colquitt, J., Lepine, J., Wesson, M. (2013). Organi- 
zational Behavior. Third Edition. USA: McGraaw-Hill, Inc.

Das, S., Mishra, P. (2014). Employee Engagement: Developing a Conceptual Framework. The International Journal of Business \& Management. 2 ( 6): 224-229.

Dessler, G. (2005). Manajemen Sumber Daya Manusia, Edisi Sembilan (terjemahan). Jakarta: PT Indeks Kelompok Gramedia.

Fatdina. (2009). Peran Dukungan Organisasi yang dirasakan karyawan sebagai mediator pengaruh Keadilan Prosedural terhadap Perilaku Kewarganegaraan Organisasi. Jurnal Psikologi. 36 (1):1-17.

Frans, Y. (2013). Job Resources and Job Performance of Universitas Terbuka's Lectures. The Asian Conference on the Social Sciences: 366 -375 .

Gujral, K., Jain, I. (2013). Determinants and Outcomes of Employee Engagement: A Comparative Study in Information Technology Sector. International Journal of Advanced Research in Management and Social Science. 2 (5):207-220.

Gunawan, H. (2012). Loyalitas Karyawan di Indonesia Masih Rendah. Berita, diakses 5 desember 2014 dari http://mobile.kontan.co.id/news

Helen, D. (2014). Survei SDM Perbankan. Berita, diakses 5 desember 2014 dari http:// finansial.bisnis.com

Hewitt, A. (2013). 2013 Trends in Global Employee Engagement. Aon plc.

Hussain, I A., Yunus N., Ishak N A., Daud N. (2013). The Influence of Intention to Leave Towards Employee Engagement among Young Banker in Malaysia. International Journal of Business and Management. 8 (14): 89-97.

Harnoto. (2002). Manajemen Sumber Daya Manusia. Prehallindo. Jakarta

Indarjanti, P., Bodroastuti, T. (2012). Pengaruh Kemampuan, Usaha dan Dukungan Organisasi terhadap Kinerja. Disertasi. Semarang: Sekolah Tinggi Ilmu Ekonomi Widya Manggala.

Jerald, G., Baron, R. A. (2007). Behaviour in organization. Ninth edition. USA: Preenhall prentice hall.

Keitner, R., Kinicki, A., (2014). Perilaku Organisasi. Edisi Sembilan (terjemahan). Jakarta: Salemba empat.

Mathis, R L., John H. J. (2003). Human Resource Management. Tenth Edition. USA: SouthWestern Cengage Learning.

Mathis, R L., John H. J. (2011). Human Resource
Management. Thirteen Edition. USA: SouthWestern Cengage Learning.

Martin, M J. (2011). Influence of Human Resource Practices on Employee Intention to Quit. Dissertasi: 1-140.

Markos, S., Sridevi, M S. (2010). Employee Engagement: The Key to Improving Performance.International Journal of Business and Management. 5(12): 89-96.

Nahusona, H., Rahardjo, M., Rahardjo S T. (2004). Analisis Faktor-Faktor yang Berpengaruh terhadap Keinginan Karyawan untuk Berpindah. Jurnal Studi Manajemen dan Organisasi. 1 (2):16-30.

Padmakumar, R., Gantasala, V. Prabhakar. (2011). The role of Employee Engagement in workrelated outcomes. Proceedings: 1-6.

Riduwan., Kuncoro, EA. (2013). Cara Menggunakan dan Memaknai Analisis Jalur (Path Analysis), Cetakan Kedua. Bandung: Alfabeta.

Robbins, S P., Judge, T A. (2013). Organizational Behaviour. Fifteenth Edition. USA: Pearson Education Inc. Prentice Hall .

Robbins, S P., Coulter, M. (2010). Manajemen. Jilid Sepuluh. Jakarta: Erlangga.

Ryan, M (2011). Performance Perspectives. Volume 20. New York: Madison Performance Group.

Samad, S. (2006). The Contribution of Demographic: Job Characteristics, Job Satisfaction on Turnover Intention. Journal of International Management Studies. 1(1):1-12.

Sarjono, H., Julianita, W. (2011). SPSS vs Lisrel. Jakarta : Salemba Empat.

Schaufeli, W. B., \& Bakker, A. B. (2004). Job demands, job resources, and their relationship with burnout and engagement: A multisample study. Journal of Organizational Behaviour. 25: 293-315.

Siddhanta, A., Roy, D. (2010). Employee Engagement - Engaging the 21st Century Workforce. A sian Journal of Management Research: 170-189.

Suan, C L., Nasurdin, A M. (2013). Role Clarity, Supervisory Support, Peer Support, and Work Engagement of Customer- Contact Employees in Hotels : A Future research Agenda. An International Multidisciplinary Journal of Tourism. 8 (1): 315-329.

Sugiyono. (2013). Cara Mudah Menyusun Skripsi dan Thesis. Bandung: Alfabeta

Yuniarsih, T., Suwatno. (2009). Manajemen Sumber Daya Manusia. Bandung: Alfabeta. 